\title{
Vergi Affı Uygulamaları: Türkiye ve Seçilmiş Ülkeler Açısından Bir Değerlendirme ${ }^{1}$
}

\author{
Tax Amnesty Practices: An Assessment in Terms of Turkey \\ and Selected Countries
}

\section{Esra Keskin ${ }^{*}$ \\ Pelin Mastar Özcan ${ }^{* *}$}

\begin{tabular}{l} 
ARTICLE INFO \\
\hline Submitted : 26.10 .2020 \\
Revised : 28.12 .2020 \\
Accepted : 21.01.2021 \\
Available : 30.06.2021 \\
\hline iThenticate similarity \\
score: 7\% \\
\hline JEL classification: \\
H20, H22, H29 \\
\hline Keywords: \\
Tax Amnesty, Fiscal \\
Amnesty, Tax Amnesty \\
Around the World
\end{tabular}

TICLE INFO

Submitted : 26.10.2020

Revised : 28.12.2020

Accepted : 21.01.2021

Available : 30.06 .2021

iThenticate similarity

score: $7 \%$

JEL classification:

$\mathrm{H} 2 \mathrm{O}, \mathrm{H} 22, \mathrm{H} 2 \mathrm{O}$

Keywords:

Amnesty, Tax Amnesty

\begin{abstract}
A B S T R A C T
From past to present, tax amnesties have been one of the indispensable tools of fiscal policies. Although tax amnesties are generally issued on many different grounds, the most important reason for these practices is to meet the required public income quickly. Around the world, investigating the frequency of applying for tax amnesties and how the application of tax amnesties, many differences draw attention in this regard. The aim of this study is to investigate what way tax amnesty applied in Turkey and some countries. In this context, especially in the last two decades has been evaluated primarily on taxes and other fiscal amnesty in Turkey, then tax amnesty applications were examined in developed and developing some countries. Other countries subject to research are the United States of America, France, Italy, Switzerland, Russia and Indonesia. As a result of the research, it was observed that tax amnesty, especially in developing countries, is perceived as a "new source of income for the treasury" and therefore, tax amnesties is applied frequently. On the other hand, it can be said that in developed countries such as the United States of America and Switzerland, amnesties are implemented under strict control and heavy taxation conditions, thus preventing the expectations regarding amnesties in the eyes of the society.
\end{abstract}

Cite this article as: Keskin, E. \& Mastar Özcan, P. (2021). “Vergi Affı Uygulamaları: Türkiye ve Seçilmiş Ülkeler Açısından Bir Değerlendirme", International Journal of Public Finance, 6(1), 137-158.

${ }^{1}$ Bu çalışma, Manisa Celal Bayar Üniversitesi SBE’de sunulan “Türk Vergi Hukukunda Vergi Affının Anayasal Vergilendirme IIlkeleri Işığında Değerlendirilmesi” isimli yüksek lisans tezinden üretilmiştir.

* Res. Assist., Manisa Celal Bayar University, Department of Public Finance, Turkey, ORCID: 0000-00029071-6306, esra.keskin@cbu.edu.tr

** Assist. Prof. Dr., Manisa Celal Bayar University, Department of Public Finance, Turkey, ORCID: 00000001-9103-4131, pelin.mastar@cbu.edu.tr 
Keskin, E. \& Mastar Özcan, P. (2021). “Vergi Affı Uygulamaları: Türkiye ve Seçilmiş Ülkeler Açısından Bir Değerlendirme", International Journal of Public Finance, 6(1), 137-158.

\begin{tabular}{|c|c|}
\hline MAKALE BíLGISI & ÖZ \\
\hline Gönderme: 26.10 .2020 & \multirow{9}{*}{$\begin{array}{l}\text { Geçmişten günümüze vergi afları, mali politikaların vazgeçilmez } \\
\text { araçlarından biri olmuştur. Vergi afları genellikle birçok farklı gerekçeye } \\
\text { dayandırılarak çıkarılsa da aslında bu uygulamaların en önemli sebebi, } \\
\text { ihtiyaç duyulan kamu gelirinin hızlı bir şekilde karşılanmasıdır. Dünya } \\
\text { genelinde vergi aflarına başvurulma sıklığı ve afların uygulanış şekline } \\
\text { bakıldığında, bu konuda birçok farklılık dikkat çekmektedir. Bu çalışmanın } \\
\text { amacı, Türkiye ve bazı ülkelerde vergi aflarının ne şekilde uygulandığının } \\
\text { araştırılmasıdır. Bu kapsamda öncelikle Türkiye'de özellikle son yirmi yılda } \\
\text { çıkarılan vergi ve benzeri mali afların değerlendirilmesi yapılmış; daha } \\
\text { sonra gelişmiş ve gelişmekte olan bazı ülkeler kapsamında vergi affı } \\
\text { uygulamaları incelenmiştir. Araştırmaya konu olan diğer ülkeler, Amerika }\end{array}$} \\
\hline Düzeltme : 28.12 .2020 & \\
\hline : 21.01.2021 & \\
\hline : 30.06.2021 & \\
\hline $\begin{array}{l}\text { iThenticate benzerlik } \\
\text { oranı: } \% 7\end{array}$ & \\
\hline JEL Kodu: & \\
\hline $\mathrm{H} 2 \mathrm{O}, \mathrm{H} 22, \mathrm{H} 29$ & \\
\hline Anahtar Kelimeler: & \\
\hline Vergi Affı, Mali Af, & \\
\hline Dünyada Vergi Afları & Birleşik Devletleri, Almanya, Fransa, İtalya, İsviçre, Rusya ve \\
\hline & $\begin{array}{l}\text { Endonezya'dır. Araştırma sonucunda, özellikle gelişmekte olan ülkelerde } \\
\text { vergi affının "hazine için yeni bir gelir kaynağı" olarak algılandığı ve bu } \\
\text { sebeple sık aralıklarla affa başvurulduğu görülmüştür. Öte yandan Amerika }\end{array}$ \\
\hline & $\begin{array}{l}\text { Birleşik Devletleri ve İsviçre gibi gelişmiş ülkelerde, afların katı denetim ve } \\
\text { ağır vergileme koşullarıyla uygulandığı ve böylece toplum nazarında affa } \\
\text { ilişkin beklentilerin de önüne geçildiği söylenebilir. }\end{array}$ \\
\hline
\end{tabular}

\section{Giriş}

Toplumun ihtiyaç duyduğu mal ve hizmetlerin üretilmesi ile ekonomik, mali ve sosyal amaçların gerçekleştirilmesi için toplanan kamu gelirlerinden biri de vergilerdir. Devlet hazinesi açısından önemli bir yere sahip olan vergilerin; bazı zamanlarda vergi affı ve yeniden yapılandırma gibi uygulamalarla tahsil edilmediği görülür. Vergi afları özellikle devlet bütçesinin sıkıntılı olduğu dönemlerde acil gelir ihtiyacının karşılanması için uygulanır. Bu bakımdan değerlendirildiğinde vergi aflarının, genellikle ekonomik gerekçelere dayandırılarak çıkarıldığı söylenebilir.

Dünya genelinde vergi ve benzeri aflar yaygın bir şekilde kullanılmaktadır. Bu uygulamalara sıkça başvurulmasının birçok nedeni vardır. Bu nedenler kimi zaman vergi idaresi ile mükellefler arasındaki barış ve uzlaşı ortamının yeniden sağlanması; kimi zaman ise tahsilatı imkânsız hale gelen kamu alacaklarının bir an önce tahsil edilmesi ile ilişkilendirilmektedir. Bununla birlikte hükümetlerin oylarını maksimize etmek için, özellikle seçim dönemlerinden önce vergi aflarını politik bir araç olarak kullandığı da bilinmektedir. Bu değerlendirmeler ışığında vergi aflarının uygulanma sıklığında; ekonomik, mali, sosyal ve siyasi birçok faktörün etken olduğu açıktır.

Türkiye'de vergi afları neredeyse bir maliye politikası aracı gibi yoğun bir şekilde uygulanmaktadır. Türkiye'de istatistiksel anlamda ortalama iki yılda bir vergi ve benzeri mali afların uygulanması, bu durumun en önemli ispatı olarak kabul edilebilir. Bu derece sık aralıklarla çıkarılan vergi aflarının, ekonomik ve sosyal anlamda birçok alanı etkilemesi kaçınılmaz bir sonuçtur. Dolayısıyla bu aşamada, afların bu kadar sık çıkarılma sebebi ve uygulama safhası ve sonrasındaki başarı durumu önem kazanmaktadır. Buna ilaveten tüm ülkeler için önemli bir uygulama olan vergi affının, Türkiye dışında diğer ülkelerde nasıl uygulandığı araştırılmalıdır. 
Bu çalışmada öncelikle vergi aflarının daha iyi bir şekilde anlaşılabilmesi için bazı teorik bilgilere yer verilecek; daha sonra Türkiye ve bazı gelişmiş ve gelişmekte olan ülkelerde vergi aflarının nasıl uygulandığı araştırılacaktır. Bu şekilde Türkiye için vergi sisteminin temel uygulamalarından biri haline gelen vergi afları daha iyi özümsenecek ve diğer ülkelerdeki af uygulamaları hakkında bazı değerlendirmeler yapılacaktır.

\section{Vergi Affının Kavramsal Çerçevesi}

Günümüz modern devlet anlayışında, vergi sisteminin başarılı bir şekilde tasarlanabilmesi için iyi bir planlama yapılmalıdır. Bu planlama, uygulanacak vergi politikalarının etkinliği için temel hedeflerden biri olarak görülebilir. Buna karşın bazı durumlarda, söz konusu hedefe ulaşmayı engelleyen birtakım engeller ortaya çıkabilmektedir. $\mathrm{Bu}$ engeller, vergi mükelleflerinin vergi sistemine uyum sağlayamamalarına ve vergi kaçakçılığı gibi yanlış eğilimlere yönelmelerine sebep olabilmektedir. Bu bağlamda mükelleflerin üzerine düşen vergi borçlarını zamanında ödeyememeleri dolayısıyla biriken kamu alacakları, devleti af uygulamalarına başvurma konusunda teşvik edici bir unsurdur (Aksümer, 2014: 1).

Genel anlamda vergi affını tanımlamaya yardımcı olan üç bileşen bulunmaktadır. Bunlardan ilki olan "uygunluk", vergi aflarının özellikle vergi gelirleri ve mükellef grupları ile uyum içerisinde olması gerektiğini açıklamaktadır. Diğer bir unsur olan "kapsam" ise, vergi affının hangi vergi türlerini kapsayacağının belirlenmesi üzerine odaklanmaktadır. Son olarak "teşvik ve fırsatlar", hükümetlerin vergi affı vasıtasıyla mükelleflere sunduğu fırsatları ve ödenmemiş vergi ve cezaların tahsili hususunda sunduğu teşvikleri konu edinmektedir (Sanchez Villalba, 2017: 287).

Vergi affı devletin egemenlik yetkisine dayanarak; kamu hizmetlerinin finansmanında kullanmak üzere bireylerden topladığı vergi ve benzeri gelirlerin tahsilinden ve vergisel sorumlulukların yerine getirilmemesi nedeniyle doğan yaptırımlardan vazgeçmesidir (Edizdoğan \& Gümüş, 2013: 99-100). Vergi hukukunda ayrı bir müessese olarak düzenlenmeyen vergi affı, kanunlar vasıtasıyla vergi cezalarını ortadan kaldıran ve genellikle vergi aslını kapsam dahiline almayan ve bu uygulamadan faydalanacak bireyleri vergisel sorumluluklarını eksiksiz bir şekilde yerine getiren bireylere karşı avantajlı konuma getiren bir kurumdur (Avcı, 2014: 4).

Başka bir bakış açısıyla vergi affı, vergi mükelleflerinin önceki dönemlere ait vergi borçlarının affedilmesi karşılığında, belirli bir miktarda vergi ödemeleri için sunulan sınırlı bir süre olarak değerlendirilmiştir (Argyropoulou, 2018: 28). Lerman ise vergi affını, önceden belirlenmiş kısa bir süreyi kapsayan ve gelecek dönemler itibariyle tekrarlanması beklenmeyen tek seferlik bir program olarak tanımlamıştır (Lerman, 1986: 325).

Literatürde bazı zamanlarda, vergi affı ile mali affın birbirinin yerine kullanıldığı görülse de aslında bu iki kavram aynı anlama gelmemektedir. Mali af genellikle genel af kapsamında yer alan ve kesin tanımının yapılması zor olan bir kavramdır. Söz konusu 
kavram en yalın haliyle, vergi ve benzeri gelirlere ilişkin düzenlemelere aykırı şekilde davranan kişilere uygulanan yaptırımların sona erdirilmesidir (Keleş, 2002: 75).

Mali afta yalnızca vergi borçları affedilmemektedir. Mali affın kapsamında bunun yanında; vergi dışında kalan ve bütçe uygulamasından başlayıp, devletin özel hukuktan doğan ilişkilerine varan parasal ilişkiler yer almaktadır. Vergi dışında kalan diğer unsurları af bünyesinde sistematik bir şekilde incelemek zor olduğundan; diğer unsurlara kıyasla vergi affı sınırları daha net ve belirgin olan bir uygulamadır. Bu bakımdan mali affın, "mali hukuk-vergi hukuku" ayrımında da olduğu üzere, vergi affından daha kapsamlı bir uygulama olduğu varsayılabilir (Taşkın, 2010: 124).

Vergi afları, sahip olduğu genel özellikler itibariyle ceza hukukunda düzenlenen af kurumundan daha farklı bir uygulamadır. Bunun nedenleri arasında, vergi aflarının genel ve özel affa kıyasla daha farklı koşullar barındırması, affın temel amaçları arasında mali ve ekonomik kaygıların bulunması ve genellikle idari nitelikteki para cezalarının affedilmesi gibi konular yer alır. Bu bağlamda vergi affının genel özellikleri şu şekilde özetlenebilir (Sarıcaoğlu, 2018: 227; Avcı, 2014: 5; Yelman, 2017: 70; Kireçtepe \& Avcı, 2016: 149; Şenyurt, 2008: 319):

1. Vergi affı kanun ile düzenlenir.

2. Vergi affında gönüllülük esası vardır.

3. Vergi affı geçici süreliğine yürürlükte kalmaktadır.

4. Vergi affı genellikle mali ve ekonomik bunalımlar sonucunda çıkartılır.

5. Vergi affı geçmişe yürüyen bir uygulamadır ve etkileri geçmiş olaylar üzerinedir.

6. Vergi affı, vergiye ilişkin temel kanunlarda düzenlenmediğinden sui generis niteliğe sahiptir.

Vergi politikaları özelinde vergi afları, bazı amaçların gerçekleştirilmesinde etkin bir araç olarak kullanılabilir (Şenyüz, 2011: 250-251). Tarihsel bir perspektifle bakıldığında, hükümetlerin bazı hedefler doğrultusunda vergi affına başvurduğu görülür. Bunlardan ilki, vergi affının hızlı bir gelir sağlama aracı olarak kullanılmasıdır. ikinci amaç ise, gelecek dönemlere ilişkin vergi uyumunun arttırılmak istenmesidir. Son olarak, acil bir şekilde gelir sağlamanın ötesinde; ödemeler dengesi, yerel yatırımlar ve finansal sistemdeki unsurlar gibi önemli konularda vergi affının kolaylaştırıcı bir araç olarak kullanılmak istenmesidir (Baer \& Borgne, 2008: 6).

Vergi affının öncelikli amacı, vergi borçlarının ve fer'ilerinin belirli bir seviyesinde ya da tamamında indirim yapmak üzere, kamu alacaklarının tahsilatını hızlandırmaktır (Öner, 2012: 161). Bu bakımdan vergi affı, birikmiş ve tahsilatı güç durumda olan vergi alacaklarının, kısmen de olsa tahsilatına imkân sağlaması, herhangi bir sonuca varılmamış vergisel işlemlerin eritilmesi ve idarenin iş yükünün azaltılabilmesi için oldukça önemli faydalar sunmaktadır (Akdoğan, 2017: 106). Öte yandan vergi aflarının uygulanmasında, sosyal ve siyasi amaçlar da bulunmaktadır. Vergi aflarında sosyal amaç, vergi mükelleflerinin geçmiş yıllardaki hatalarının 
affedilmesi ve vergi alacaklısı-vergi borçlusu ilişkisinde temiz bir sayfa açılmasıdır. Bu bakımdan hükümetler vergi aflarını kullanarak, mükelleflere geçmiş hatalarını telafi edebilmeleri hususunda bir şans vermeyi amaçlayabilir (Bayer vd., 2015: 71). Son bir değerlendirme olarak, vergi aflarının çıkarılmasındaki siyasi amaca da değinmek gerekir. Politikacıların genellikle vergi aflarını, bir "seçim vaadi" olarak kullandığı bilinmektedir. Bunun temel nedeni, politikacıların vergi aflarını kullanarak oylarını maksimize etmek istemesidir. Dolayısıyla vergi afları, ekonomik anlamda ihtiyaç duyulmadığı zamanlarda bile politik bir araç olarak kullanılmaktadır. Örneğin Türkiye'de, özellikle 1960 ve 1980 yılları arasında çıkarılan vergi aflarının çoğunluğu, genel af kanunları ile yürürlüğe giren ve siyasi sebepleri ağır basan af uygulamaları olarak bilinmektedir (Bülbül \& Karadeniz, 2004: 804).

Vergi aflarının farklı şekillerde uygulanan kendine has türleri vardır. Literatürde vergi aflarının türleri genellikle, "süre", "kapsam" ve "düzeltme, inceleme ve kovuşturma" gibi unsurlar dahilinde incelenmektedir. Süre açısından vergi affı sınıflandırmasında temel kriter olarak, vergi affının uygulanış süresi dikkate alınmaktadır. Vergi affı kanunlarının hangi döneme ilişkin borçları af kapsamına alacağı, affın başlangıç ve bitiş dönemleri ve geçmişe dönük vergi borçlarının af kanununun yürürlüğe girmesinden itibaren belirli bir süre içinde affedilmesi gibi unsurlar, bu sınıflandırma için önemlidir. Öte yandan vergi affının süreli veya süresiz olabilme ihtimali de bu sınıflandırma altında yorumlanabilir. Vergi afları genellikle iki veya üç aylık kısa dönemler itibariyle uygulanmaktadır. Buna karşın Türkiye'de son dönemlerde uygulanan vergi aflarının süresinin birçok kez uzatıldığı ve hatta "affın affı" şeklinde uygulamaların gerçekleştirildiği de görülmektedir (Yurdadoğ \& Coşkun Karadağ, 2017: 139).

Kapsam açısından vergi affı sınıflandırmasında temel kriter olarak, vergi affının hangi tür vergileri kapsayacağı hususu dikkate alınmaktadır. Bu sınıflandırmada önemli olan bir diğer ölçüt vergi affının; vergi aslı, gecikme zammı, gecikme faizi ve vergi cezaları gibi unsurlardan hangilerini kapsayacağına ilişkindir (Özkanca Andıç, 2014: 56). Literatürde vergi affının yalnızca vergi cezaları ve vergi aslına ilişkin gecikme faizi gibi unsurları konu edinmesi ve vergi aslının af kapsamında değerlendirilmemesi gerektiği savunulmaktadır. Bu durumun gerekçesi, vergi aslının kısmen veya tamamen affedilmesi hususunun anayasaya uygun olmadığı düşüncesi ile açıklanmaktadır (Arıkan \& Yurtsever, 2004: 2).

Düzeltme affı ile vergi mükelleflerinin hesapları yeniden kontrol edilmek üzere, eksik beyan ettikleri veya gizledikleri matrahların belirli şartlar altında ve genellikle ceza ödemeden beyan etmelerine fırsat sağlanmaktadır. Buna ilaveten bu düzeltme affında, devletin mükellefler üzerindeki inceleme ve denetleme hakkı hiçbir zaman ortadan kalkmamaktadır (Erol, 2011: 142). Inceleme affında ise, aftan faydalanan mükelleflerin vergi matrahlarını belirli şartlar dahilinde düzeltmelerine izin verilmektedir. $\mathrm{Bu}$ af türünde devletin, mükelleflerin geçmiş dönemlere ilişkin hesaplarını inceleyebilme hakkı vardır (Erol, 2005: 4). Son olarak kovuşturma affında, vergi affından faydalanan mükellefler için bazı ödeme fırsatları sunulmakta ve bu fırsatlar dahilinde kamu alacağının belirli bir kısmından vazgeçilmekte ve daha önceden 
başlamış olan vergi incelemelerine de hukukî bakımdan son verilmektedir (Yıldız Şeren \& Dedebek, 2013: 9-10). Dolayısıyla bu af türünün en önemli özelliği, tahsili zora düşen veya imkânsız hale gelen kamu alacaklarını tahsil edebilmek için, mükellefler hakkında önceden başlatılan kovuşturmalara son verilmesidir.

Çalışmanın bu bölümünde son olarak, vergi affına ilişkin görüşler neticesinde af kurumunun eleştirisine yer verilmiştir. Vergi afları konusunda literatürde birçok farklı düşünce olduğu söylenebilir. Bu bilgiden hareketle, vergi aflarına ilişkin görüşler Tablo 1 aracılığıyla şu şekilde özetlenebilir:

Tablo 1: Vergi Aflarına iliş̧kin Görüşler

\begin{tabular}{|c|c|}
\hline Vergi Aflarına Yönelik Olumlu Eleştiriler & Vergi Aflarına Yönelik Olumsuz Eleştiriler \\
\hline $\begin{array}{l}\text { Vergi tahsilatını daha kolay hale getirir ve } \\
\text { hızlandırır. }\end{array}$ & $\begin{array}{l}\text { Vergi adaleti ve eşitlik başta olmak üzere temel } \\
\text { vergilendirme ilkelerini zedeler. }\end{array}$ \\
\hline $\begin{array}{l}\text { Tahsili imkânsız hale gelen kamu alacaklarının } \\
\text { tahsili açısından vergi gelirlerini arttırır. }\end{array}$ & Mükellefleri vergi kaçakçılığı hususunda özendirir. \\
\hline İdare & $\begin{array}{l}\text { Vergi kanunları ve diğer düzenlemelere karşı uyumu } \\
\text { azaltır. }\end{array}$ \\
\hline $\begin{array}{l}\text { Vergi kaybına yol açmış kişiler için temiz bir } \\
\text { sayfa açılmasına yardımcı olur. }\end{array}$ & $\begin{array}{l}\text { Vergi suçları tasarlanarak işlendiğinden affedilmeye } \\
\text { lâyık bir unsur değildir. }\end{array}$ \\
\hline $\begin{array}{l}\text { Siyasi, ekonomik ve mali bunalımlar } \\
\text { sonrasında gerekli bir uygulamadır. }\end{array}$ & $\begin{array}{l}\text { Uzun vadede gelirlerin artması hususunda katkı } \\
\text { sağlayamaz. }\end{array}$ \\
\hline $\begin{array}{l}\text { Affa konu olan eylemi gerçekleştiren kişilerin, } \\
\text { vergi sistemine daha uyumlu hale getirilmesini } \\
\text { teşvik eder. }\end{array}$ & $\begin{array}{l}\text { Devlete olan güveni zedelemekte ve gelecek } \\
\text { dönemlerde yeni bir affın olmayacağına ilişkin inancı } \\
\text { azaltmaktadır. }\end{array}$ \\
\hline
\end{tabular}

Kaynak: Kargı, 2011: 105-106; Yurdadoğ \& Coşkun Karadağ, 2017: 138.

Vergi aflarını olumlu veya olumsuz anlamda eleştiren görüşler, affın ekonomik, toplumsal ve hukukî boyutu üzerinde yoğunlaşmaktadır. Afların olumlu bir uygulama olduğunu savunanlar, affın mali getirisi ve hata yapan mükellefler için yeni bir dönemin açılması gibi konulara vurgu yaparken; afları olumsuz anlamda eleştirenler ise daha çok vergi uyumu, vergi adaleti ve hukukî uygunluk gibi konular üzerinde durmaktadır. Bu bilgiden hareketle, ortak bir mutabakatın olmaması sebebiyle vergi afları, uzun yıllardır tartışılan uygulamalardan biri olmuştur. Bu durum vergi aflarını olağan bir vergi politikası aracı gibi sık aralıklarla kullanan gelişmekte olan ülkelerde, afların kamuoyunu sürekli meşgul eden ve birçok açıdan gerekliliği tartışılan bir uygulama haline gelmesine yol açmıştır.

\section{Türkiye'de Vergi Afları}

\subsection{Türkiye'de Vergi Aflarının Gelişimi}

Bir devletin kuruluşuna ilişkin en önemli gerekçelerden biri vergilendirmedir. Türkiye Cumhuriyeti'nin kuruluşunda 1 numaralı Kanunun, Ağnam-ı Resmiyye Kanunu 
adında bir vergi kanunu olması, bu iddiayı ispatlar niteliktedir. Ağnam kelimesinin karşılığı "koyun" olup; sözü edilen verginin konusunu küçükbaş hayvanlar oluşturmaktadır. Görüldüğü üzere Türkiye Cumhuriyeti de birçok devlet gibi, vergilemeye ilişkin bir kanun ile doğmuştur (Bingöl, 2019a: 25). Vergilemeye yönelik bir kanun ile doğan Türkiye Cumhuriyeti'nin, birtakım fiskal ve ekstra fiskal amaçları gerçekleştirmek için sıkça kullandığı araçlardan biri de vergi aflarıdır. Türk vergi hukukunda vergi affı ile ilgili ilk hukukî düzenleme, 1906 yılında Irade-i Seniye kapsamında yol vergisine ilişkin cezaların sona erdirilmesi ile gerçekleşmiştir. Zaman içerisinde vergi sistemimizde sıkça uygulanmaya başlanan aflar ciddi bir probleme dönüşmeye başlamış ve kurumsal bir hal almıştır. Öte yandan af sorununun kronikleşmesine karşın affın genel işleyişine yönelik ciddi bir iyileşme gerçekleştirilememiş ve kanun koyucu dönemin şartları doğrultusunda hareket etmeye devam etmiştir (Dönmez, 1990: 12-13).

Cumhuriyetin kuruluşu ile birlikte vergi affına ilişkin ilk düzenleme, 1928 yılında yürürlüğe giren 145 sayılı Elviyei Selâsede Vergilerinin Sureti Cibayetine Dair Kanun ile olmuştur. Söz konusu düzenleme ile birlikte 1960’lı yıllara kadar çıkarılan vergi aflarında temel amacın, geçmişte uygulanan vergi ve benzeri mali yükümlülüklerin tasfiyesini gerçekleştirmek olduğu söylenebilir. Yine bu dönemde çıkarılan vergi aflarında, vergi cezalarının hiçbir surette affedilmediği dikkat çekmektedir. Ilerleyen dönemde özellikle 1961 yılında yürürlüğe giren, 281 sayılı Bir Kısım Vergi Cezaları ile Gecikme Zamlarının Tecil ve Tasfiyesine Dair Kanun ile birlikte vergi aflarında yeni bir dönemin başladığı söylenebilir. Zira söz konusu düzenleme ile birlikte Türk vergi hukukunda ilk kez vergi cezaları da af kapsamına alınmıştır. Bundan sonraki tüm af düzenlemeleri ise hem vergi aslı hem de vergi borcuna bağlı unsurları ve cezaları af konusunda değerlendirmeye bağlamıştır. Öte yandan 1980'li yıllarda vergi affına ilişkin düzenlemelerin, vergi kanunlarına eklenen "geçici maddeler" ile yapıldığı dikkat çekmektedir. Bu bağlamda vergi affına ilişkin özel bir düzenleme yerine; çeşitli kanunlara eklenen geçici maddeler yardımıyla af hükümleri uygulanmıştır.

Günümüzde Türkiye'de vergi ve benzeri aflar çok sık aralıklarla uygulanmaktadır. Bu açıdan bakıldığında, vergi aflarının neredeyse bir maliye politikası aracı gibi sürekli kullanılan bir uygulama haline geldiği söylenebilir. Bir ülkede vergi aflarının bu derece sık kullanılan bir araç haline gelmesinin birçok olumsuz sonucu vardır. Bu sonuçlara; vergi tahsil kabiliyetinin yitirilmesi ve vergi alacaklarının neredeyse normal şartlar dahilinde toplanamayacak hale gelmesi örnek olarak verilebilir. Başka bir açıdan vergi afları, özellikle aftan yararlanmayan ve vergi ödevine sadık kalarak vergisel yükümlülüklerini yerine getiren mükellefler nezdinde "haksızlığa uğradıkları" düşüncesine sebebiyet vermektedir. Özellikle vergi aflarının Anayasa'nın 10'uncu maddesinde düzenlenen "kanun önünde eşitlik" ve 73'üncü maddeden çıkarılan "vergilendirmede eşitlik" ilkeleriyle uyumsuzluğu da afların olumsuz sonuçları arasında değerlendirilebilir. Bilindiği üzere eşitlik ilkesinin vergi ödevine yansıması olarak kabul edilen "vergilendirmede eşitlik ilkesine" göre vergi yükümlüleri, yatay ve dikey adalet prensibi dahilinde vergilendirilmelidir. Bu bağlamda mali güç temel kriter 
olup, normal şartlarda aynı oranda vergilendirilmesi gereken, ancak vergi affı nedeniyle vergisel borç ve yükümlülüklerden kurtulan bazı kişilerin durumu hukukî anlamda birçok tartışmaya konu olmaktadır. Bu bilgiler ışığında çalışmanın bu kısmında Türkiye'de uygulanan vergi aflarının daha iyi bir şekilde incelenebilmesi adına, özellikle son yirmi yılda çıkarılan vergi afları konu edinilecek ve bu afların genel bir değerlendirilmesi yapılacaktır.

\subsection{Türkiye'de 2001 Yılı ve Sonrasında Uygulanan Vergi Afları}

Türkiye'de 2001 yılı ve bunu takip eden dönem, ekonomik ve siyasal açıdan oldukça sıkıntılı bir süreç olarak değerlendirilebilir. Özellikle 2001 yılında patlak veren finansal kriz, tahminlerin ötesinde bir ekonomik daralmayı beraberinde getirmiş ve Türkiye'nin orta vadeli hedeflerini ciddi düzeyde etkilemiştir. Öte yandan bu yıllarda Türkiye, kronik hale gelen yüksek enflasyon problemini ortadan kaldıramamış sayılı ülkeden biridir. Dolayısıyla bu yıllar, Türkiye ekonomisine ciddi zararlar veren unsurların ortadan kaldırılması ve kurumsal yenilenmenin daha sağlıklı bir şekilde gerçekleştirilmesi için çalışılan bir dönem olarak görülebilir (Celasun, 2002).

Türkiye Cumhuriyeti'nin kuruluşundan itibaren birçok vergi affı uygulanmış; ancak bu afların yaklaşık üçte biri son yıllarda çıkarılmıştır. Bu dönemde uygulanan afların gerekçeleri arasında; bütçe açıklarının kapatılması, kamu gelirlerinin arttırılması, ülkeye has ekonomik sorunların ve kayıt dışılığın çözümlenmesi gibi hususlar yer almaktadır (Bingöl, 2019b). Bu bağlamda vergi aflarının genellikle kamu geliri ihtiyacının yoğun olduğu dönemlerde uygulandığı bilinmektedir. Nitekim uygulanan vergi afları sonucunda, hazineye önemli miktarda gelir akışının sağlandığı dönemler olmuştur. Örneğin, 2003 tarih ve 4811 sayılı Kanun'dan yaklaşık 3.475 .144 mükellef yararlanmış ve hazineye kayda değer miktarda bir gelir aktarılmıştır. Buna göre söz konusu af sonucunda, eski para ile yaklaşık 4,7 katrilyon Türk Lirası değerinde bir gelir elde edilmiştir. İlerleyen dönemde, 2008 tarih ve 5811 sayılı Varlık Barışı düzenlemesi ile toplam 64 bin 567 beyanname ile başvuru yapılmış ve vergi matrahı 48,3 milyar TL olarak hesaplanmış; bunun sonucunda hesaplanan ve ödenmesi gereken vergi miktarı ise 1,6 milyar TL olmuştur. Benzer olarak, 2011 yılında yürürlüğe giren ve en geniş kapsamlı af kanunlarından biri olarak kabul edilen 6111 sayılı Kanun ile yaklaşık 39,4 milyar TL yeniden yapılandırılmış ve ilk taksit ödemelerinde \% 81 oranında rekor bir tahsilat düzeyi gerçekleşmiştir (Yaraşır, 2013: 185). 2016 tarih ve 6736 sayılı Kanun ile birlikte, 41 milyar TL değerinde bir gelir elde edilmiş ve haliyle söz konusu düzenleme, son yıllarda yapılan aflar arasında en başarılı uygulamalardan biri haline gelmiştir. Son olarak 2017 tarih ve 7020 sayılı Kanun ile 5 milyar 624 milyon TL ve 2018 tarih 7143 sayılı Kanun kapsamında, yaklaşık 25 milyar 583 milyon TL değerinde bir tahsilat yapılmış ve bu miktar toplam yapılandırılan kamu alacağının yalnızca \%32,9'unu oluşturmuştur. Bu bilgiler ışığında, Türkiye'de 2001 yılı ve sonrasında uygulanan vergi ve benzeri aflar Tablo 2' de gösterilmektedir: 
Keskin, E. \& Mastar Özcan, P. (2021). “Vergi Affı Uygulamaları: Türkiye ve Seçilmiş Ülkeler Açısından Bir Değerlendirme", International Journal of Public Finance, 6(1), 137-158.

Tablo 2: Türkiye'de 2001 Yılı ve Sonrasında Uygulanan Vergi Afları

\begin{tabular}{|c|c|}
\hline Tarih & Kanun \\
\hline 06.02 .2001 & 414 sayılı Tahsilât Genel Tebliği \\
\hline 03.04.2002 & $\begin{array}{l}4751 \text { sayılı Vergi Usul Kanunu, Emlak Vergisi Kanunu ve Harçlar Kanununda Değişiklik } \\
\text { Yapılmasına İlişkin Kanun'un Geçici 21'inci Maddesi }\end{array}$ \\
\hline 25.02 .2003 & 4811 sayılı Vergi Barışı Kanunu \\
\hline 13.11.2008 & 5811 sayılı Bazı Varlıkların Milli Ekonomiye Kazandırılması Hakkında Kanun \\
\hline 13.02.2011 & $\begin{array}{l}6111 \text { sayılı Bazı Alacakların Yeniden Yapılandırılması ile Sosyal Sigortalar ve Genel Sağlık } \\
\text { Sigortası Kanunu ve Diğer Bazı Kanun ve Kanun Hükmünde Kararnamelerde Değişiklik } \\
\text { Yapılması Hakkında Kanun }\end{array}$ \\
\hline 21.05.2013 & $\begin{array}{l}6486 \text { sayılı Sosyal Sigortalar ve Genel Sağlık Sigortası Kanunu ile Bazı Kanunlarda } \\
\text { Değişiklik Yapılmasına Dair Kanun }\end{array}$ \\
\hline 10.09.2014 & $\begin{array}{l}6552 \text { sayılı İş Kanunu ile Bazı Kanun ve Kanun Hükmünde Kararnamelerde Değişiklik } \\
\text { Yapılması ile Bazı Alacakların Yeniden Yapılandırılmasına Dair Kanun }\end{array}$ \\
\hline 03.08.2016 & 6736 sayılı Bazı Alacakların Yeniden Yapılandırılmasına İlişkin Kanun \\
\hline 18.05.2017 & $\begin{array}{l}7020 \text { sayılı Bazı Alacakların Yeniden Yapılandırılması ile Bazı Kanunlarda ve Bir Kanun } \\
\text { Hükmünde Kararnamede Değişiklik Yapılmasına Dair Kanun }\end{array}$ \\
\hline 11.05.2018* & $\begin{array}{l}7143 \text { sayılı Vergi ve Diğer Bazı Alacakların Yeniden Yapılandırılması ile Bazı Kanunlarda } \\
\text { Değişiklik Yapılmasına İlişkin Kanun }\end{array}$ \\
\hline 17.07.2019* & 7186 sayılı Gelir Vergisi Kanunu ile Bazı Kanunlarda Değişiklik Yapılması Hakkında Kanun \\
\hline
\end{tabular}

* Tabloda faydalanılan kaynakların dışında tarafımızca eklenmiştir.

Kaynak: Yelman, 2017: 76-77; Yılmaz, 2019: 89.

Tablo 2'de görüldüğü üzere, Türkiye'de 2001 yılı ve sonrasında vergi ve benzeri unsurlara ilişkin aflarının uygulanabilmesi için on bir farklı düzenleme yapılmıştır. Bu açıdan bakıldığında, Türkiye'de ortalama iki yılda bir vergi ve benzeri mali afların uygulandığı görülmektedir. Bu istatistiki sonuç, Türk vergi sisteminin temel dinamikleri hakkında önemli ipuçları vermektedir. Buna göre vergi idaresinin kamu alacaklarının tahsil kabiliyetini neredeyse yitirdiği, hazinenin acil gelir ihtiyacının sürekli olduğu ve vergi aflarının vergi politikasının vazgeçilmezlerinden biri haline geldiği rahatlıkla söylenebilir.

Bir ülkede vergi aflarının bu derece sık aralıklarla uygulanması, vergi ödevinin kutsallığına ve mükelleflerin vergiye karşı bakış açısına zarar vermektedir. Özellikle vergi zihniyeti ve ahlâkı açısından bu durum tehlikeli sonuçlara yol açabilir. Ortalama iki yılda bir yürürlüğe giren vergi affı kanunları, vergilendirmenin alacaklı ve borçlu tarafı özelinde herhangi bir şaşkınlık yaratmamaktadır. Zira vergi mükellefleri "nasılsa yine af çıkar" beklentisi içerisine girerek; temel vergisel ödev ve sorumluluklarını yerine getirme konusunda ihmalkâr davranmaktadır. Bu durum, Türkiye'de vergi kayıp ve kaçaklarının yüksek olmasının nedenlerinden yalnızca biridir. 
Tablo 2 gereğince dikkat çeken bir diğer konu, vergi affı kanunlarına verilen isimler ile ilgilidir. Görüldüğü üzere çıkarılan on bir farklı vergi affı kanununun hiçbirinde "af" kavramı yer almamaktadır. Bu durum, sosyolojik ve hukukî açıdan iki farklı şekilde açıklanabilir:

Vergi affı kanunlarına "vergi barışı, varlık barışı, yeniden yapılandırma" gibi isimlerin verilmesindeki sosyolojik neden; toplumun af kanunlarına ilişkin olumsuz bakış açısı ile ilgilidir. Hangi konuda yapılacağı önemli olmamakla birlikte; bir düzenlemenin adında "af" kelimesi yer aldığında, toplum tepkisi genellikle olumsuz yöndedir. Bu durum, hukuka ve kanunlara karşı gelmeyen insanların affı haksız bir uygulama olarak görmesinden kaynaklanmaktadır.

Vergi affı kanunlarında af kavramının tercih edilmemesinin hukuki sebebi ise, parlamentonun bu düzenlemelere "af kanunu" muamelesi yapmamasıdır. Normal şartlarda Anayasa gereğince af kanunları, Meclis üye tam sayısının beşte üç çoğunluğu ile yürürlüğe girmek zorundadır. Ancak nitelikli çoğunluğu sağlamak zor olduğundan; vergi affı kanunlarına verilen başka isimlerle birlikte af kanunlarının normal karar alma çoğunluğu ile yürürlüğe girdiği görülmektedir. Türkiye'de özellikle son otuz yılda çıkarılan vergi affı kanunlarında bu durum rahatlıkla görülebilir. Bu durum özellikle verginin kanuniliği ilkesi olmak üzere, birçok anayasal vergileme ilkesine aykırı bir uygulamadır.

Son bir değerlendirme olarak; Türkiye'de son yirmi yılda çıkarılan vergi affı kanunlarının kapsamına ve konu edindiği unsurlara değinmek önemli olacaktır. Bu dönemde çıkarılan af kanunları, genellikle vergi cezaları ve vergi borcunun fer'ilerini affetmekte; buna karşın vergi aslını af kapsamına almamaktadır. Bu bakımdan değerlendirildiğinde, bir mükellefin ilgili vergi affından faydalanabilmesi için, vergi aslının ödenmesi koşulunun öne sürüldüğü görülmektedir. Öte yandan bu dönemde çıkarılan vergi ve benzeri mali aflarda, yurt dışında bulunan ekonomik varlıkların ülkeye kazandırılması adına çıkarılan af kanunları dikkat çekmektedir. Bu kanunlara literatürde "varlık barışı" da denilmektedir. Yine bu dönemde "torba kanunlar" aracılığıyla, birçok vergi ve benzeri kamu gelirine ilişkin çeşitli afların getirildiği de bilinmektedir.

\section{Dünyada Vergi Afları}

Dünyada vergi afları yoğun bir şekilde kullanılsa da bu uygulamanın tarihi serüveni çok eski zamanlara dayanır. Tarihte vergi affına ilişkin ilk yazılı belgeler Mısır'da M.Ö 200 yıllarında, toplumsal karışıklıkların sonlandırılması için vergiyi reddedenlerin affedilmesini konu edinen Rosetta Stone kayıtlarında yer almıştır. Öte yandan vergi affının Roma İmparatorluğu'nda M.S 401, 411, 434, 445, 450 ve 458 yıllarında da uygulandı̆̆ı bilinmektedir (Torgler, 2003: 619-620). Günümüzde vergi afları, ülkeler çapında ulusal af uygulamaları kapsamında yaygın bir şekilde kullanılmaktadır (Das-Gupta \& Mookheriee, 1996: 409).

Çalışmanın bu kısmında vergi aflarının, diğer ülkelerde nasıl uygulandığı araştırılacaktır. Bu bağlamda ilgili araştırmada, dünyanın farklı bölgelerinden gelişmişlik 
seviyesine göre yedi farklı ülke seçilmiştir. Ülke seçiminde; vergi aflarının uygulanma sıklığı ve nasıl uygulandığı, af öncesi ve sonrası mali politikaların durumu ve vergi affının kullanılış biçimi gibi kriterler dikkate alınmıştır.

\subsection{Amerika Birleşik Devletleri'nde Vergi Afları}

Amerika Birleşik Devletleri, eyalet düzeyinde vergi affını en sık uygulayan ülkelerden biridir. Özellikle 1980'li yıllardan itibaren birçok eyalet, mali programlarında vergi aflarına yer vermiştir. Bu yıllarda otuz eyalet tarafından sayısı otuz beşe yakın birçok vergi affı uygulanmış ve bunlardan özellikle Florida, Illinois ve Louisiana vergi affını aktif bir araç olarak sıklıkla kullanmıştır. 1990'lı yıllara gelindiğinde, vergi affının uygulama sıklığı kayda değer bir şekilde azalmış ve söz konusu dönemde vergi affı uygulamalarına on sekiz kez başvurulduğu görülmüştür. Bu durumun aksine 2000'li yıllar, vergi affı açısından önemli bir dönem olmuş ve bu süreçte sayısı altmışa yakın birçok vergi affı uygulanmıştır. Bu yıllarda çıkarılan afların üçte birinin, 2010 ile 2012 yılları arasında uygulanması da dikkat çekici bir durumdur (Mikesell \& Ross, 2012: 533-534).

Amerika Birleşik Devletleri'nde vergi afları, genellikle eyalet düzeyinde tercih edilen bir uygulamadır. Bu bağlamda özellikle Arizona ve Massachusetts, 1980'li yıllardan itibaren vergi affı uygulamalarında öne çıkan iki eyaletten biridir. Arizona eyaleti yaşanan bir bütçe krizi sonucunda ilk vergi affını 1982 yılında uygulamış ve bunun sonucunda yaklaşık altı milyon dolar gelir elde etmişken; Massachusetts eyaleti ise 1983 yılında, dönemin en başarılı vergi affı uygulamalarından birini gerçekleştirerek, yaklaşık seksen dört milyon dolar gelir elde etmiştir. Öte yandan aynı dönem aralığında (1985-1986) altı eyalet daha vergi affı uygulamalarına başvurarak, bazı ekonomik kazanımlar elde etmeye çalışmıştır (Parle \& Hirlinger, 1986: 246-249).

Amerika Birleşik Devletleri'nde uygulanan vergi aflarında, kanun koyucu genellikle üç amaç üzerinde yoğunlaşmaktadır. Bu amaçlar genel itibariyle; "bir defaya mahsus olmak üzere gelir elde edebilmek", "vergi beyannamesi vermeyenlerin tespitinin sağlanması sonucunda gelecek dönemlerdeki vergi gelirlerini arttırmak" ve "vergiye gönüllü uyumu desteklemektir". Bu amaçların gerçekleştirilebilmesi için yükümlülüklerini belgeleme konusunda zorluk çeken veya bu hususları hiç anlayamayan mükelleflerin ödenmemiş vergi borçlarını ödemesi şartıyla, bu kişilere yönelik hukukî ve cezai yaptırımlar kayda değer bir şekilde hafifletilmiştir. Amerika Birleşik Devletleri'nde birçok eyalet vergi aflarını tüm vergileri kapsayacak şekilde uygularken; California gibi bazı eyaletlerde bu durum yalnızca gelir ve satış vergileri gibi sınırlı alanlarda gerçekleşmektedir (Martinez, 1991: 543-544).

Amerika Birleşik Devletleri'nde uygulanan aflardan sonra gerçekleştirilen programlar sayesinde; vergiden kaçınma konusunda geçmişe kıyasla daha az tolerans gösterilmiş ve birçok eyalet buna ilişkin idari ve adli cezaları arttırmıştır. Örneğin, New York'ta vergi aflarına ilişkin veriler kayıt altına alınmaya başlamış ve bu bireysel profiller, yeni denetim tekniklerinin geliştirilmesinde kullanılmış; Colorado'da ise yeni 
çapraz kontrol teknikleri geliştirilmiş ve eyalette kazanılan tüm gelirlerin vergileme açısından değerlendirilmesi ve tahsilatı için raporlar oluşturulmuştur. Dolayısıyla bu noktada "cezalandırma" ve "yaptırım", vergi affı hususunda kilit taşı görevi görmektedir. Vergi sisteminde uygulanan ağır yaptırımların, af gelirleri üzerinde oldukça güçlü bir etkisi vardır. Çünkü vergi affı sonrasında hiçbir şeyin eskisi gibi olmayacağını ve denetimlerin çok daha katı kurallarla gerçekleştirileceğini bilen mükellefler, vergi affından faydalanma hususunda acele edecektir. Öte yandan etkin bir cezalandırma sisteminin kurulmasıyla birlikte, gelir tahsilatının yaklaşık on milyon dolar arttığı görülmüştür (Alm \& Beck, 1991: 1050-1052).

\subsection{Almanya'da Vergi Afları}

Günümüzde vergi affı uygulamalarına yönelik politik ilginin Almanya gibi gelişmiş ülkelerde de görülmesi, bu konunun önemini daha çok arttırmaktadır (Torgler, 2003: 661). Buna karşın Almanya gibi vergi uyumu bakımından güçlü bir ülkenin; diğer ülkelere kıyasla vergi aflarını çok sık kullanmadığı bilinmektedir. Almanya'da vergi afları, genellikle vergi sisteminde veya vergi kanunlarında meydana gelecek köklü değişiklikler sırasında gündeme gelmektedir (Turan \& Güler, 2020: 25). Bu bakımdan ilgili ülke, vergi affı uygulamalarını yerinde ve zamanında kullanmaya çalışmaktadır.

Almanya'da vergi affı genellikle olağanüstü dönemlerde uygulanmıştır. Birinci Dünya Savaşı'ndan hemen önce 1913 yılında, "Savaşa Katkı Yasası (Wehrbeitragsgesetz)" kapsamında; 1914 yılında gelir ve servetini beyan eden mükellefler için vergi aslı ve cezalarına ilişkin vergi affı uygulanmıştır. İlerleyen yıllarda özellikle Nasyonal Sosyalizm diktatörlüğünde birçok vergi affı uygulanmıştır. 1949 yılında kurulan Federal Almanya Cumhuriyeti döneminde bu durum değişmemiş ve bu yıllarda iki farklı vergi affı uygulaması görülmüştür. Buna karşın söz konusu vergi affı programları kamuoyu nezdinde beklentileri karşılayamamış ve 1988 yılına kadar yeni bir vergi affı uygulanmamıştır. 1988 yılında uygulanan vergi affı, önceki aflara kıyasla oldukça sınırlı bir kapsamda hazırlanmış ve yalnızca sermaye kazançları hususunda af getirilmiştir. Dolayısıyla bu vergi affının geçmiş uygulamalara kıyasla başarılı olduğunu söyleyebilmek oldukça zordur (Kellner, 2004: 340).

İlerleyen yıllarda, 1990 yılında yürürlüğe giren af kanunu ile faiz gelirini daha önce beyan etmemiş veya eksik beyan etmiş mükelleflerin, görevlerini yerine getiren dürüst mükellefler arasına katılabilmeleri amaçlanmıştır. Söz konusu hedefe ulaşabilmek adına, Türk vergi sistemindeki "pişmanlık ve ıslah" müessesine benzeyen bir düzenleme yapılmıştır. Buna karşın söz konusu vergi affı pişmanlık müessesesini aşan, çok boyutlu bir uygulama haline dönüşmüştür. Örneğin; 1986 yılı öncesinde vergi kaçakçılı̆̆ı kapsamında değerlendirilen vergi asılları dahi af kapsamına alınmıştır. Öte yandan vergi affından yararlanabilmek için verilen af beyannameleri çift yönlü şekilde değerlendirilebilir. Bu beyannameler sayesinde işlenen vergi suçları cezasız bırakılmakta ve 1986 yılından önceki döneme ait gelir ve servet vergileri affedilmektedir (Dönmez, 1990: 169-171). 
2003 yılında vergi kaçıran mükelleflerin vergiye gönüllü uyumunu arttırabilmek adına hazırlanan bir kanun ile bu kişilere yönelik bir vergi affı uygulanmıştır. Söz konusu affın uygulanabilmesi için; 1993 ile 2002 yılları arasında kara para aklayıp bu unsurları yüksek faizler karşıı̆ı̆nda işleten ve vergilendirilmemek için Almanya dışına aktaran kişilerin, bu maddi varlıkları yurt içine getirmesi ve buna ilişkin vergilerin bazı indirimler dahilinde ödenmesi şartı koyulmuştur (Can, 2004: 47).

Almanya'da uygulanan vergi aflarının genel özelliklerine bakıldığında; afların genellikle on beş ay gibi uzun süreler ile uygulandığı dikkat çekmektedir. Öte yandan mükelleflerin geçmiş dönemlerde ödemediği vergilere ilişkin verilen cezalar, diğer ülkelere kıyasla oldukça ağır şartlar içermektedir. Söz konusu ceza oranları genellikle \% 35 oranında uygulanmakta ve dolayısıyla Almanya'da vergi aflarının, katı kurallar çerçevesinde uygulandığı bir kez daha görülmektedir (Devroe, 2005: 219). Öte yandan vergi aflarının Almanya'da özellikle 1990'lı yıllara kadar belirli aralıklarla uygulandı̆̆ı; ancak daha sonra bu tür uygulamaların çok fazla tercih edilmediği bilinmektedir. Bununla birlikte çıkarılan vergi afları da kapsam olarak sınırlı bir kazanç grubuna yöneliktir. Bu bakımdan Almanya, gelişmiş ülkeler arasında vergi affı uygulamalarını az kullanan ülkeler arasındadır.

\subsection{Fransa'da Vergi Afları}

Fransa'da vergi affı uygulamalarının tarihi oldukça eskidir. Fransa'da ilk vergi affı kanununun 1800 'lü yıllarda hazırlanması da bu iddiayı destekler niteliktedir. Bu tarihten sonra vergi afları Fransa için kurumsal bir niteliğe dönüşmüş; ancak afların genel yapısı itibariyle günümüzde uygulanan vergi aflarından uzak bir görüntü çizilmiştir (Dönmez, 1990: 139-140). Öte yandan Fransa'da 1948, 1982 ve 1986 yıllarında uygulanan vergi aflarının da ülke ekonomisinde özel bir yeri vardır.

Fransa'da, 1948 yılında uygulanan vergi affında Maliye Bakanı, ülke dışında bulunan maddi kaynakların \% 25 oranında vergilendirilmesi şartıyla yurt içine dönüşüne izin vermiştir. Buna göre söz konusu uygulama, milli varlıkların ekonomiye kazandırılması adına önemli bir adımdır (Malherbe, 2011: 72). Benzer bir sebeple 1982 yılında hazırlanan vergi affı programına göre; yurt dışında yasadışı şekilde tutulan sermayenin yurt içine kazandırılması amaçlanmıştır. 1982 yılında uygulanan vergi affı programı genel af şeklinde hazırlanmış ve tüm Gelir ile Katma Değer Vergilerine uygulanmıştır. Ancak söz konusu vergi affı uygulamasına yalnızca 2786 kişi katılmış ve bu programdan yaklaşık on dokuz milyon dolar gelir elde edilmiştir. Aynı yıl ülke genelinde ikinci bir af programı hazırlanmış ve bu programa sadece 276 kişi katılmıştır. Söz konusu vergi affı programından yaklaşık yirmi iki milyon dolar elde edilmiştir. Buna karşın 1982 yılında uygulanan bu iki program da Fransa'da uygulanan yüksek oranlı servet vergisi nedeniyle başarılı olamamıştır (Luitel, 2014: 16).

1986 yılında hazırlanan vergi affı programı da diğer af uygulamalarında olduğu gibi yurt dışında bulunan varlıkların ülkeye kazandırılması amacıyla hazırlanmıştır. Ancak bu af programında; söz konusu varlıkların ülkeye getirilmesinde uygulanacak 
olan vergilendirme oranı \% 10 olarak belirlenmiştir. Buna göre önceki yıllarda uygulanan vergi afları, servet vergisine ilişkin yüksek oranlar nedeniyle başarısız olduğu için; ilgili verginin oranında indirime gidilerek affa katılımın yüksek olması amaçlanmıştır (Guttman, 1992: 66; Joint Committee on Taxation, 1998: 32; Luitel, 2014: 16).

Fransa Anayasa Mahkemesi'ne 1986 yılında uygulanan vergi affı özelinde başvuru yapılmış ve ilgili Mahkeme bu düzenlemenin hukukî açıdan uygulanabilir olduğuna karar vermiştir. Ayrıca ilgili kararda söz konusu kanunun "vergilendirmede eşitlik ilkesine" aykırı olduğu; ancak bu uygulamanın kamu yararı için yapıldığı gerekçesiyle sakıncalı bir duruma yol açmadığı belirtilmiştir. Burada belirtilen kamu yararı ile vergiye gönüllü uyum konusunda sorun yaşayan mükelleflerin daha dikkatli olması ve yurt dışında bulunan varlıkların ulusal ekonomiye kazandırılması kastedilmektedir (Malherbe, 2011: 73).

Çoğu ülkede olduğu gibi, Fransa'da da vergi affına yönelik özel bir mevzuat bulunmamaktadır. Ancak yurt dışında bulunan kayıt dışı varlıkların mükellefler tarafından gönüllü olarak beyan edildiği durumlarda; vergi cezalarının azaltılması idari bir politika olarak uygulanmaktadır. Buna ek olarak 20 Nisan 2009'da Fransa Maliye Bakanlığı, bu kayıt dışı varlıkların beyanını teşvik etmek için, vergi cezaları ve buna ilişkin faizlerde indirim kararı almıştır. Ancak bu kararın tam anlamıyla bir vergi affı uygulaması olduğunu söylemek yanlış bir değerlendirme olacaktır (Malherbe, 2011: 73).

\section{4. İtalya'da Vergi Afları}

Ittalya'da ilk vergi affı, 11 Kasım 1900 tarihinde bir Kraliyet Kararnamesi ile uygulanmış ve bununla birlikte ülke ekonomisinde vergi afları kalıcı bir politika haline gelmiştir. Bu bağlamda, ulusal düzeyde ortalama iki yılda bir vergi affının çıkarılması da bu iddiayı kanıtlar niteliktedir. Bunun sonucunda normal şartlar dahilinde olağanüstü bir araç olan vergi afları, İtalya vergi sisteminde sabit ve sürekli bir uygulama haline dönüşmüştür (Malherbe, 2011: 17-18).

İtalya'da 1973 tarihinden itibaren vergi afları genellikle kararnameler ile yürürlüğe girmekte ve birçoğu "özel vergi affı" şeklinde hazırlanmaktadır. Buna karşın İtalya'da "genel vergi affı" yalnızca; 1973, 1982, 1991 ve 2003 yıllarında uygulanmış ve bu aflar sayesinde daha önceden beyan edilmemiş vergiler eksiksiz bir şekilde tahsil edilebilmiştir. Öte yandan uygulanan bu afların oldukça benzer özelliklere sahip olduğu bilinmektedir (Purnomolastu, 2017: 79; Luitel, 2014: 18).

İtalya'da özellikle 1991 ile 2014 yılları arasında birçok vergi affı uygulanmıştır. $\mathrm{Bu}$ af programlarında, mükelleflerin mevcut vergi borçlarını daha düşük oranlarda ödeyebilmeleri amaçlanmış ve her af uygulamasından sonra hükümet yetkilileri, bir daha vergi affı olmayacağını ve bunun son bir fırsat olduğunu dile getirmişlerdir. Ancak uygulamada görüldüğü üzere bu durum söylendiği şekilde gerçekleşmemiş ve vergi afları sistemin kalıcı bir unsuru haline gelmiştir. 2001 yılında Berlusconi Hükümeti tarafından, Avrupa Birliği mali düzenlemelerini ihlal etmeyecek bir şekilde hazırlanan 
ve İtalya'da beyan etmemek için yurt dışına aktarılan mali kaynakların tekrar yurt içine kazandırılmasına yönelik bir af kanunu yürürlüğe girmiştir. Bu vergi affı ile devlet hazinesine yaklaşık iki milyon euro kaynak girişi sağlanırken; aslında yurtdışında bulunan kaynakların yalnızca \% 11'i ülkeye tekrar kazandırılabilmiştir (Huda \& Hernoko, 2017: 60).

2014 yılında uygulanan vergi affında, yurt dışında bulunan ekonomik varlıkların ülke içerisinde gönüllü bir şekilde beyan edilmesi amaçlanmıştır. Bu vergi affı sayesinde vergi mükellefleri, yurt dışında bulunan varlıklara ilişkin raporlar sunmuş ve daha sonra bu varlıklar için hesaplanan vergi borçlarını ödemişlerdir. Bu uygulama ile mükelleflere, ödemeleri gereken vergi borcunu hafifleten cezalar kesilmiş ve böylece af sonrası ödedikleri vergi ve cezalar, affın yerine yapılacak vergi incelemesi sonucunda ortaya çıkacak miktardan daha az olmuştur (Huda \& Hernoko, 2017: 60).

İtalya'da vergi afları sık aralıklarla tekrarlanan bir mali politika olduğu için, affın etkinliği hususunda istenmeyen sonuçlar ortaya çıkmaktadır. Örneğin; 1982 yılında uygulanan vergi affında yaklaşık beş milyar dolar değerinde bir kazanç elde edileceği öngörülürken, uygulamada yalnızca yedi yüz bin dolar tahsil edilebilmiştir. Buna karşın İtalya, vergi aflarını uygulama hususunda karar değişikliğine gitmemiştir. Bu durum ulusal vergi uyumu seviyesinin düşük olmasında, vergi aflarının çok önemli bir faktör olmasının temel nedenleri arasında gösterilmektedir (Joint Committee on Taxation, 1998: 33).

\section{5. İsviçre'de Vergi Afları}

İsviçre'de vergi afları genellikle kantonlar (eyalet) düzeyinde kullanılan bir uygulama iken; özellikle İkinci Dünya Savaşı'ndan sonra ulusal düzeyde gerçekleştirilen vergi afları da bulunmaktadır. Kantonlarda uygulanan vergi aflarına bakıldığında, ilk affın 1917 yılında Zürich kantonunda uygulandığı görülmektedir. İlerleyen dönemlerde 1938 yılına kadar; Graubünden, Fribourg, Valais (3 kez), Lucerne, Cenevre (2 kez) ve Basel, Glarus gibi birçok kantonun, vergi aflarını bir mali araç olarak kullanmaya başladığı dikkat çekmektedir. Öte yandan İsviçre kantonlarında uygulanan vergi aflarının başarısı, ulusal düzeyde gerçekleştirilen vergi aflarına bağlıdır. Bu durum mükelleflerin kantonlarda yer alan vergi affından faydalanmadan önce, ulusal düzeyde hazırlanan vergi affına katılmaları ile ilgilidir. Mükelleflerin bu davranışlarının altında, kanton vergi idareleri tarafından kişilere ilişkin mükellefiyet bilgilerinin, federal vergi idaresine bildirilmesi korkusu yatmaktadır. Bu düşünce ile beraber mükellefler hem kanton hem de federal düzeyde uygulanan vergi aflarının ikisine de katılmak zorunda kalmaktadır (Torgler \& Schaltegger, 2005: 6).

İsviçre'de 1940 yılında, İkinci Dünya Savaşı'ndan sonra ortaya çıkan savunma harcamalarını finanse edebilmek amacıyla yeni bir vergi arayışı başlamıştır. Bu bağlamda söz konusu yıllarda hükümet yetkilileri, yalnızca bir seferlik alınacağı duyurulan olağanüstü bir Emlak Vergisi uygulamasına başlamıştır. Ülke kanunlarına göre normal şartlarda referanduma gidilerek koyulması gereken bu tür vergiler, savaş 
yıllarına özel bir durum nedeniyle hükümetin genişletilmiş yasal yetkisine dayanarak, referandum yapılmadan uygulamaya konulmuştur. Söz konusu uygulamada, mükelleflerin vergiye gönüllü uyumunu teşvik edebilmek amacıyla yalnızca kaçırılan emlaklara ilişkin genel bir vergi affı uygulanmış; ancak bu vergilere ilişkin cezalar hakkında herhangi bir af getirilmemiştir. Buna karşın söz konusu vergi affından beklenilen gelir elde edilememiştir (Luitel, 2014: 21-22; Torgler \& Schaltegger, 2005: 6).

1944 yılına gelindiğinde ulusal düzeyde yeni bir af programı hazırlanmış ve bu uygulama bir önceki vergi affına kıyasla oldukça başarılı bir şekilde uygulanmıştır. Bu vergi affının sonucunda devlet hazinesine önemli derecede kaynak tahsisi sağlanmış ve vergi affının mükellefler üzerinde olumsuz bir etki bırakmaması ve vergilemenin altında yatan temel fikrin kaybolmaması nedeniyle vergi oranı \% 15'ten \% 25'e çıkarılarak uygulanmıştır. Bu uygulama ile daha önce ekonomik varlıklarını beyan etmeyen mükellefler teşvik edilmeye çalışılmış ve vergi affı sıkı kontrol ve denetimler altında gerçekleştirilerek, kantonlar arasında etkin bir bilgi alışverişi sağlanmaya çalışıımıştır (Torgler, 2003: 626; Torgler \& Schaltegger, 2005: 10).

1960'lı yıllarda, ülkenin genel ekonomik koşulları gereğince yeni bir vergi affı uygulaması gündeme gelmiştir. 1962 yılında federal parlamento yeni bir vergi affı tasarısı üzerinde çalışmaya başlamış; ancak bu çalışmalar federal hükümet tarafından destek bulamamıştır. Bu durumun temel nedeni olarak hükümet yetkilileri, gelişmiş uygulamalar olmadan güncel bir vergi affına gerek olmadığını savunmuş ve bu nedenle söz konusu tasarıyı eleştirmiştir. Bu tartışmalar altında söz konusu tasarı ile 1964 yılında referanduma gidilmiş ve referandum sonucunda ilgili vergi affı tasarısı halk oylamasından geçememiştir (Pommerehne \& Zweifel, 1991: 132). Bu bağlamda değerlendirildiğinde İsviçre, vergi affı tasarısının halk tarafından reddedildiği gelişmiş bir ülke örneği olarak karşımıza çıkmaktadır (Pepper, 1966: 290). Ancak 1968 yılında söz konusu tasarı için bir kez daha referanduma gidilmiş ve bu tasarıda önceki uygulamalara benzer bir taslak hazırlanmış ve mevcut denetim uygulamaları değiştirilmemiştir. Buna karşın referandum sonucunda, vergi affı tasarısı halk oylamasından geçmeyi başarmıştır (Pommerehne \& Zweifel, 1991: 132).

İsviçre'de ilerleyen yıllarda meydana gelen ekonomik problemler neticesinde, yeni bir vergi affına gerek duyulup duyulmadığı uzun bir süre tartışılmıştır. Bununla birlikte yeni bir vergi affına ilişkin bu tartışmalar, genel bir vergi affının çıkarılmasını destekleyecek önemli bir halk çoğunluğuna ulaşamamıştır. Bu durumun temel nedeni, genel vergi aflarının mükellefler üzerinde olumsuz ahlâki sonuçlar oluşturacağı endişesinden kaynaklanmaktadır (Malherbe, 2011: 40).

\subsection{Rusya'da Vergi Afları}

Rusya, 1990 ile 2000'li yıllar arasında yoğun bir şekilde vergi kaçırılan ve vergi tahsilatının yapılmasında sorunlar yaşayan bir ülke olarak değerlendirilebilir. Rusya'da vergi otoriteleri, sözü edilen bu problemleri ortadan kaldırmak için çabalasa da ülkenin vergi sisteminde yer alan problemler 2000 yılında Cumhurbaşkanı seçilen Vladimir 
Putin'den sonra kısmen de olsa çözümlenmeye başlamıştır. Bu bağlamda Rusya'nın vergi sisteminde bulunan problemlerin çözümünde kullanılan araçlardan biri de vergi afları olmuş; özellikle 1993 yılından itibaren birçok vergi affı uygulaması gerçekleştirilmiştir (Alm, 2009: 241; Morozov, 1996: 44).

Rusya'da 19 Ocak 1996 yılında yürürlüğe giren bir Cumhurbaşkanlığı Kararnamesi ile ulusal düzeyde bir vergi affı çıkarılmıştır. Söz konusu vergi affı kapsamında işletme ve diğer kuruluşlara; vergi borçlarını zamanında ve eksiksiz olarak ödemek şartıyla, bu borçları bir mühlet daha ödememe hakkı getirilmiştir. Bu erteleme hakkından yararlanan mükellefler, 1998 yılının Ekim ayına kadar toplam vergi borcunun \% 50'sini ödemek ile yükümlü tutulmuş ve borcun ödenmeyen kısmı için de yıllık \% 30 oranında faiz işleneceği duyurulmuştur. Buna ek olarak kalan vergi borcunun yarısının, beş yıl boyunca eşit taksitlerle ve faizsiz olarak ödeneceği belirtilmiştir. Söz konusu bu uygulama, ilgili dönem şartlarında yüksek maliyetli ve mükellefler için büyük sorumluluklar yüklenen bir vergi affı olarak değerlendirilmiştir (Alm vd., 2009: 241).

Rusya ilerleyen yıllarda da vergi affının daha iyi bir şekilde uygulanması için herhangi bir gelişme gösterememiştir. Bu bakımdan değerlendirildiğinde Rusya'nın vergi affı konusunda başarılı bir ülke olduğu söylenemez. Özellikle vergi idaresinin nitelik itibariyle yetersiz olması nedeniyle vergi afları, vergi kaçakçılığı gibi suçlarla başa çıkabilmenin kolay bir mücadele yolu olarak kabul görmüştür. Ayrıca ulusal düzeyde neredeyse her yıl çıkarılan vergi afları, bu uygulamanın sürekli bir şekilde devam edeceği hususunda endişeler yaratmaktadır (Luitel, 2014: 20).

\subsection{Endonezya'da Vergi Afları}

Endonezya'da vergi afları çeşitli dönemler itibariyle uygulanmış (1964, 1984, 2008 ve 2016); ancak bu af uygulamalarının hepsi başarılı olarak görülmemiştir. Özellikle bu yıllarda çıkarılan vergi affı programları, oldukça katı kurallar çerçevesinde dizayn edilse de affın gerçekleştirilme sürecinde daha yumuşak ve ılımlı bir şekilde hareket edilmiştir. Öte yandan 1964 ve 1984 yılında uygulanan vergi aflarının başarısızlıklarından ders alınarak 2016 yılında kadar, Endonezya vergi idaresi yetkililerinin güçleri yasal anlamda kademeli olarak arttırılmıştır. Buna karşın Endonezya vergi sisteminde uygulanan vergi aflarının çoğunlukla, mevcut yasal veya yasal olmayan gelir kaynaklarını dikkate almaktan daha çok; ek vergi koyabilme arayışları içerisinde olan programlar olduğu ifade edilmektedir (Sudarma \& Darmayasa, 2017: 13).

Endonezya'da 1964 yılında uygulanan vergi affı, bir Cumhurbaşkanlığı Kararnamesi ile yürürlüğe girmiştir. Söz konusu af programı ile ulusal çıkarların korunması ve genel olarak ülke büyüme ve kalkınmasına destek olunması ve 1963 yılında hazırlanan ekonomik programların daha kolay bir şekilde uygulanması hedeflenmiştir (Huda \& Hernoko, 2017: 54-55). Bu vergi affında 17 Ağustos 1965 yılından önce kayıt altına alınmayan ve bu af sayesinde yetkili kurumlara bildirimi yapılan maddi varlıklara ilişkin Kurumlar Vergisi, Gelir Vergisi ve Servet Vergileri 
kapsamında vergi indirimleri yapılmıştır. Öte yandan bu vergi affı kapsamında, vergi idaresinin çalışma alanına giren gelir kaynaklarına ilişkin inceleme ve denetim hakkına yönelik herhangi bir kısıtlama ve müdahale olmamıştır (Darmawan, 2016: 516).

1984 yılında uygulanan vergi affı programı ile ülkenin büyüme ve kalkınmasına yardımcı olmak amacıyla hazırlanan yeni vergi sisteminin daha kolay bir şekilde uygulanabilmesi amaçlanmıştır. Buna ek olarak söz konusu uygulama ile ülke mevzuatında yer almadığı için vergilendirilemeyen potansiyel gelirin kayıt altına alınması hedeflenmiştir. Öte yandan bu kayıp gelir kaynaklarının, mükelleflerin söz konusu maddi varlıkları daha düşük vergi oranı olan ülkelere aktarması sonucunda oluştuğu bilinmektedir (Huda \& Hernoko, 2017: 55).

Endonezya'da 2016 yılında uygulanan vergi affının amaçları arasında; 2016 ile 2017 yılları arasında vergi gelirlerini ve gelecek dönemlere ilişkin vergi uyumunu arttırmak, yurt dışına transfer edilen maddi varlıkların ülke içerisine geri dönüşünü teşvik edebilmek, yeni vergi sistemine uyumu arttırmak ve ülke içerisinde bir uzlaşma ortamı sağlamak gibi unsurlar bulunmaktadır. 2016 yılında uygulanan vergi affı, geçmiş dönemdeki uygulamalara kıyasla oldukça başarılı bir af uygulamasıdır. Bunun temel nedeni söz konusu af programı sayesinde; 2016 yılında toplanılması hedeflenen gelir miktarının \% 74'ünün toplanarak, yaklaşık iki yüz otuz milyar dolar vergi tahsilatı yapılmasıdır. Bu bağlamda değerlendirildiğinde Endonezya, güncel şartlar altında vergi affı konusunda başarılı ülkeler arasında değerlendirilebilir (Ibrahim vd., 2017: 222).

\section{Sonuç}

Türkiye'de vergi afları, olağanüstü bir vergi politikası aracı olmaktan çıkmıştır. Özellikle son yirmi yılda uygulanan aflara bakıldığında; vergilerin normal tahsil yöntemlerinden daha çok vergi afları aracılığıyla toplanılmaya çalışıldığı görülmektedir. $\mathrm{Bu}$ durum vergi yönetimine ilişkin problemlerin varlı̆̆ına işaret etmektedir. Vergi aflarının bu derece yoğun bir şekilde kullanılması, mükelleflerin sürekli bir af beklentisi içinde olmasına yol açmaktadır. Bu durum vergi bilinci ve zihniyetini olumsuz yönde etkilemektedir.

Türkiye'de vergi aflarının başarılı bir şekilde uygulanıp uygulanmadığını anlayabilmek için diğer ülke uygulamalarına bakmak gerekir. Bu bağlamda Türkiye, çalışma kapsamında seçilen gelişmiş ülkelere kıyasla; vergi affı konusunda başarılı bir ülke olarak değerlendirilemez. Bunun en önemli göstergesi, vergi affından beklenen sonuçların alınmaması nedeniyle üzerinden birkaç yıl bile geçmeden, yeni bir af düzenlemesinin gündeme gelmesidir. Özellikle gelişmiş ülkeler açısından bakıldığında, vergi affına sıkça başvurulmaması ve af uygulaması sonrasında katı ve ağır denetimlerin gerçekleştirilmesi, affın başarılı bir şekilde uygulanmasında önemli bir paya sahiptir. Örneğin Amerika Birleşik Devletleri'nde eyalet düzeyinde gerçekleştirilen vergi aflarına bakıldığında; Türkiye gibi bu uygulamalara sıkça yer verildiği görülmektedir. Buna karşın af sonrasında yapılan ağır vergi denetim ve kontrolleri, mükellefleri bir daha hata yapmamaları konusunda yönlendirmektedir. Bununla birlikte Amerika Birleşik 
Devletleri'nde uygulanan her vergi affı sonrasında, sistemde yer alan eksiklikler ve hangi gerekçelerle vergi affına ihtiyaç duyulduğu araştırılmakta ve mevcut problemlerin çözümüne yönelik somut adımlar atılmaktadır. Bu durum, vergi affı uygulamalarının başarısında önemli bir kilometre taşıdır.

Çalışma kapsamında incelenen Almanya ve İsviçre'nin, vergi affı uygulamalarını yerinde ve zamanında kullanmaya dikkat ettiği görülmektedir. Söz konusu ülkelerde vergi aflarının, ekonomik ve mali bunalım dönemlerinde kullanılması ve bunun dışındaki dönemlerde af uygulamalarından kaçınııması dikkat çekmektedir. Öte yandan bu ülkelerde vergi aflarının katı kurallarla birlikte uygulandığı bilinmektedir. Bunlara, vergi oranlarının normal koşullara kıyasla kayda değer miktarda arttırılarak uygulanması ve af sonrası denetim ve incelemelerin daha sert şekilde gerçekleştirilmesi örnek olarak verilebilir. Özellikle af kapsamına alınan vergilere ilişkin oranların önemli düzeyde arttırılarak uygulanması, vergi aflarının vergisel yükümlülüklerini yerine getirmek istemeyen kişiler için güvenli bir liman olarak kullanılmasına izin vermemektedir. Bunun yanında özellikle İsviçre'de, vergi affı uygulamasına ilişkin karar yetkisinin "referandum" aracılığıyla halkın kararına bırakıldığı örnekler mevcuttur. Bu durum vergi affı kararlarının sadece, "vergilendirme ve bütçe hakkının" esas sahibi olan toplum tarafından verilebileceğine ilişkin önemli bir sembol niteliğindedir.

Fransa ve İtalya'da vergi afları, 1800 ve 1900 'lü yıllardan itibaren uygulanan önemli müesseselerden biridir. Ancak bu ülkelerde vergi aflarının tarihi ve köklü bir geçmişi bulunmasına rağmen; afların başarılı bir şekilde uygulandığına ilişkin bir değerlendirme yapılamamaktadır. Bunun en önemli gerekçelerinden biri, özellikle af sonucunda beklenen tahmini gelir ile tahsil edilen gelir arasında önemli farklılıklar bulunmasıdır. Bu bağlamda iki ülke özelinde, vergi affı uygulamalarında ekonomik anlamda bir başarısızlığın olduğu açıktır. Öte yandan Fransa'da vergi afları genellikle, yurt dışında bulunan ekonomik varlıkların milli ekonomiye kazandırılması adına "varlık barışı" şeklinde uygulandığı dikkat çekmektedir.

Araştırma sonucunda değinilmesi gereken son ülkeler ise Rusya ve Endonezya'dır. Rusya'da vergi aflarının kurumsal bir gelenek içinde "hazineye kaynak sağlama" amacıyla kullanıldığı bilinmektedir. Bununla birlikte çıkarılan vergi aflarından ekonomik anlamda istenilen verimin alınmaması ve ülkenin kronik problemlerinden vergi kayıp ve kaçaklarıyla mücadelede afların yanlış bir politika aracı olarak kullanılması, af konusundaki başarısız uygulamaların gerekçeleri arasındadır. Türkiye ve Rusya'ya kıyasla Endonezya, gelişmekte olan ülkeler arasında vergi aflarını başarılı bir şekilde uygulamaktadır. Ülkede vergi aflarının ilk uygulamalarına bakıldığında, afların "potansiyel bir gelir sağlama aracı" olarak görüldüğü dikkat çekmektedir. Ancak günümüzde, vergi afları daha doğru bir şekilde uygulanmakta ve ihtiyaç duyulmadıkça vergi aflarına başvurulmamaktadır. Öte yandan 2016 yılında gerçekleştirilen vergi affı, tahsil edilen gelir miktarı açısından diğer gelişmekte olan ülkelere örnek olacak niteliktedir. 


\section{Kaynakça}

Akdoğan, A. (2017). Vergi Hukuku ve Türk Vergi Sistemi, Gazi Kitabevi, Ankara.

Aksümer, E. (2014). "Geçmişten Günümüze Vergi Afları ve Sonuçlarının Değerlendirilmesi", Lebib Yalkın Mevzuat Dergisi, 129, 1-16.

Alm, J. \& Beck, W. (1991). "Wiping the Slate Clean: Individual Response to State Tax Amnesties", Southern Economic Journal, 57(4), 1043-1053.

Alm, J., Martinez-Vazquez, J. \& Wallace, S. (2009). "Do Tax Amnesties Work? The Revenue Effects of Tax Amnesties During the Transition in the Russian Federation", Economic Analysis \& Policy, 39(2), 235-253.

Arıkan, Z. \& Yurtsever, H. (2004). “Türkiye'de Mali Affın Nedenleri, Etkileri ve SonuçlarıI", Yaklaşım, 136, 1-4.

Argyropoulou, V. (2018). "Coming in from the Cold: The Latest Tax Amnesty in Greece and Lessons for the Future", U.C. Davis Journal of International Law \& Policy, 24(2), 125-134.

Avcı, M. A. (2014). "Güçlü Ekonomiye Geçiş Programı Sonrası Vergi Aflarının Merkezi Yönetim Bütçesi Üzerindeki Mali Etkisi”, Legal Mali Hukuk Dergisi, 10(118), 1-12.

Bayer, Ralph C., Oberhofer, H. \& Winner, H. (2015). "The Occurence of Tax Amnesties: Theory and Evidence", Journal of Public Economics, 125, 70-82.

Bingöl, O. (2019a). Vergi Sistemini Anlama Kılavuzu (Bir Halkın Vergi ile Imtihanı), Tekin Yayınevi, Ankara.

Bingöl, O. (2019b). “Yeni Bir Vergi Affı Çıkar mı?”, http://vergiyedair.com/2019/03/22/ yeni-birvergi-affi-cikar-mi/, (22.03.2019).

Bülbül, D. \& Kabakçı Karadeniz, H. (2004). "Vergi ve Sigorta Prim Aflarının Kayıt Dışı Ekonomi Üzerine Etkisi", 19. Türkiye Maliye Sempozyumu, Mayıs 2004, Antalya.

Can, i. (2004). "Almanya'da Devletin Yapısı ve Vergi Sisteminin Anayasal Temelleri", Maliye Dergisi, 145, 37-96.

Celasun, M. (2002). "2001 Krizi, Öncesi ve Sonrası: Mikroekonomik ve Mali Bir Değerlendirme", http://content.csbs.utah.edu/ ehrbar/erc2002/pdf/i053.pdf

Darmawan, A. (2016). "Indonesia's Tax Amnesty Law Based on the Perspective the Law as an Allocative System", Yustisia Journal Hukum, 5(3), 509-527.

Das-Gupta, A. \& Mookherjee, D. (1996). "Tax Amnesties as Asset-Laundering Devices", Journal of Law, Economics, \& Organization, 12(2), 408-431.

Devroe, W. (2005). "Tax Amnesty and Community Law", Maastricht Journal of European and Comparative Law, 12(3), 217-225.

Dönmez, R. (1990). "Teoride ve Uygulamada Vergi Afları", Yayımlanmış Doktora Tezi, Anadolu Üniversitesi Sosyal Bilimler Enstitüsü, Eskişehir. 
Edizdoğan, N. \& Gümüş, E. (2013). “Vergi Afları ve Türkiye'de Vergi Aflarının Değerlendirilmesi", Maliye Dergisi, 164, 99-119.

Erol, A. (2005). "Vergi Afları ve Parlamento Etkisi", Lebib Yalkın Mevzuat Dergisi, 24, 185-191.

Erol, A. (2011). Vergi Felsefesi (Devlet ve Vergi), İstanbul Serbest Muhasebeci Mali Müşavirler Odası Yayınları, İstanbul.

Guttman, G. (1992). "Tax Indulgences: the Scope and Effect of Tax Amnesty", Tax Adminstration Review, 11, 63-70.

Huda, M. K. \& Hernoko, Y. (2017). "Tax Amnesties in Indonesia and Other Countries: Opportunities and Challenges", Asian Social Science, 13(7), 52-61.

Ibrahim, A. M., Myrna, R., Irawati, I. \& Kristiadi, J. B. (2017). “A Systematic Literature Review on Tax Amnesty in 9 Asian Countries", International Journal of Economics and Financial Issues, 7(3), 220-225.

Joint Committee on Taxation. (1998). Tax Amnesty, U.S Government Printing Office, Washington.

Keleş, Y. (2002). "Yine Mi Af? Mükellefler Ne Zaman Vergi Öderler?”, Vergi Dünyası Dergisi, 249, 75-84.

Kellner, M. (2004). “Tax Amnesty 2004/2005- An Appropriate Revenue Tool”, German Law Journal, 5(4), 339-346.

Kireçtepe, B. O. \& Avcl, O. (2016). "Teorik ve Tarihsel Çerçevede Vergi Afları: 6736 Sayılı Kanun'un İncelenmesi”, Vergi Sorunları Dergisi, 339, 146-158.

Lerman, A. H. (1986). "Tax Amnesty: the Federal Perspective" National Tax Journal, 39(3), 325-332.

Luitel, H. S. (2014). Is Tax Amnesty Good Tax Policy?: Evidence from State Tax Amnesty Programs in the United States, Lexington Books, UK.

Malherbe, J. (2011). Tax Amnesties, Kluwer Law International, Holand.

Martinez, L. P. (1991). "Federal Tax Amnesty: Crime and Punishment Revisited", Virginia Tax Review, 10, 535-584.

Mikesell, J. L. \& Ross, J. M. (2012). "Fast Money? The Contribution of State Tax Amnesties to Public Revenue Systems", National Tax Journal, 65(3), 529-562.

Morozov, A. (1996). "Tax Administration in Russia", East European Constitutional Review, 39-47.

Öner, E. (2012). Vergi Hukuku ve Türk Vergi Sistemi, Seçkin Yayıncılık, Ankara.

Özkanca Andıç, N. (2014). “Türkiye'de Vergi Afları ve Afların Gönüllü Vergi Uyumu Üzerindeki Etkisi", Mali Kılavuz, 56-69.

Parle, W. M. \& Hirlinger, M. W. (1986). "Evaluating the use of Tax Amnesty by State Governments", Public Administration Review, 46(3), 246-255. 
Pepper, H. W. T. (1966). “Tax Amnesties”, British Tax Review, 5, 284-296.

Pommerehne, W. W. \& Zweifel, P. (1991). "Success of a Tax Amnesty: At the Polls, for the Fisc?", Kluwer Academic Publishers, 72, 131-165.

Purnomolastu, N. (2017). "Comparison of Tax Amnesty Implementation in Devoloping Countries", Jurnal Bisnib Terapan, 1(1), 77-85.

Sanchez Villalba, M. A. (2017). "On the Effects of Repeated Tax Amnesties", Journal of Economics and Political Economy, 4(3), 286-301.

Sarıcaoğlu, E. (2018). “Vergi Affından Yararlanan Mükellef için Mütalaa Geri Alınabilir mi?”, Türkiye Barolar Birliği Dergisi, 218-255.

Sudarma, M. \& Darmayasa, N. (2017). “Does Voluntary Tax Compliance Increase After Granting Tax Amnesty?", Accounting and Finance Review, 2(3), 11-17.

Şenyurt, í. (2008). "Türkiye'de Vergi Aflarının Nedenleri ve Sonuçları", Vergi Dünyası Dergisi, Sayı:319, Mart, 2008, http://vergidunyasi.com.tr/dergiler.php?id=4949, (20.08.2020).

Şenyüz, D. (2011). Vergi Ceza Hukuku, Ekin Yayınevi, Bursa.

Taşkın, Y. (2010). "Vergi Aflarının Hukuki Niteliği ve Gerekçeleri", Sosyal Bilimler Dergisi, 2, 122-128.

Torgler, B. \& Schaltegger, C. A. (2005). "İsviçre'de ve Dünyada Vergi Afları”, Legal Mali Hukuk Dergisi, 9, 1-13.

Torgler, B. (2003). "Tax Morale: Theory and Empirical Analysis of Tax Compliance", Yayımlanmış Doktora Tezi, Basel Üniversitesi, https://edoc.unibas.ch/56/1/ DissB_6463.pdf.

Turan, M. E. \& Güler, H. (2020). "Türkiye ve Bazı OECD Ülkelerindeki Vergi Aflarının Kanuni Dayanaklarının Karşılaştırılması, Vergi Raporu Dergisi, 252, 11-32.

Yaraşır, S. (2013). "Vergi Afları ve Türkiye'deki Vergi Aflarının Değerlendirilmesi”, Vergi Dünyası Dergisi, 379, 175-187.

Yelman, E. (2017). “Türkiye'de Çıkarılan Vergi Aflarının Nedenleri ve 6736 Sayılı Kanun'un Mali Yönden İncelenmesi”, Yalova Sosyal Bilimler Dergisi, 7(15), 67-84.

Yıldız Şeren, G. \& Dedebek, E. (2013). "Yeni Varlık Varışı (6486 Sayılı, Sosyal Sigortalar ve Genel Sağlık Sigortası Kanunu işe Bazı Kanunlarda Değişiklik Yapılmasına Dair Kanun", International Anatolia Academic Online Journal, 1(1), 3-23.

Yılmaz, S. (2019). Türkiye'de Vergi Affı Uygulamaları ve Kuşakların Bakış Açısı, Ekin Yayınevi, Bursa.

Yurdadoğ, V. \& Coşkun Karadağ, N. (2017). “Türkiye'de Yapılan Ampirik Çalışmalar Işığında Vergi Aflarının Değerlendirilmesi", Eurasian Business \& Economics Journal, 8, 134-164. 